\title{
The Service Architecture of Agricultural Informatization
}

\author{
Zhiyong $\mathrm{He}^{*}$, Lecai Cai, Hongchan Li, and Jujia Xu \\ Institute of Computer Application, Sichuan University of Science and Engineering, \\ Zigong Sichuan, P.R. China 643000, \\ Tel.: +86-13778520180; Fax: +86-813-5505966 \\ hzy@suse.edu.cn
}

\begin{abstract}
Agricultural informatization is the basis for the modernization of agriculture, at present there are many different ways of construction and models in agricultural information systems. Agricultural informatization for the Theory and Application of the status quo, a comparative analysis of a typical agricultural information system, agricultural information service system architecture is advanced, discussed in detail the operating mechanism of service, standards and application of norms, information platform architecture and other major issues, for the construction of agricultural informatization technology standards and norms of the project has a reference value.
\end{abstract}

Keywords: agricultural informatization, service architecture, framework.

\section{Introduction}

Agricultural informatization is the strategy of rejuvenating the implementation and prospering rural market economy, promote solve problems of "agriculture, countryside and farmers", promoting the construction of rural well-off, agricultural science and technology service system is the important part of the construction. It is the vital significance to construct the agriculture information service system of agricultural informationization, and to improve the level of agricultural modernization and agricultural comprehensive competitiveness.

At present, the agriculture information service system has no unifying definition. Some articles which are related to agricultural information service system aims at agricultural informationization, of development; provides agricultural information service all kinds of main agricultural information service as the core, consist the organic system according to certain rules and system(Yingbo Li et al., 2005). Rural information service system is an integral component which it is engages in the organization of the rural information service, personnel, information infrastructure, information resources and the necessary information technology (Liang Xue et al., 1998). An organic whole is integrated by the agricultural information service system, it has agricultural information resource, agriculture information service participants, policies

\footnotetext{
${ }^{*}$ Corresponding author.
} 
and regulations, operation mechanism, information infrastructure, and information technology, etc, agricultural information collection and processing, the spread and application are realized, its purpose is to provide technology and organization of agricultural informatization and security.

\section{Domestic and Overseas Status}

\subsection{Overseas Status}

The agriculture information service system as an important support system in the market economy developed countries. The market information service system construction is strengthened, the agriculture information legislation is noticed, International cooperation and agricultural market information service are strengthened, and the forceful measures construction of economic restructuring is promoted (Jing Zhao et al., 2007).

A huge market information network and information network of perfect function have been established by The United States, the policy of the development of agricultural information system is stringier (Xiangyu Zhang et al., 2005). The Japanese government attaches great importance to build a perfect agricultural market information service system, plays a folk in provide market information, and the role of computer in the popularization and application of rural (Yi Yang et al., 2005), the information service system of agricultural market as one of the key service system construction, Japanese agricultural informatization development in these successful experience is worth our using for reference. French formed government, folk, university diversified and comprehensive information service pattern and diversity of information service main body, which include the national agricultural subject, agricultural chamber, agricultural scientific research and teaching units, various agricultural industry organizations and professional associations, folk information media and various agricultural production cooperatives and mutual (Zuoyu Guo et al., 2000), etc. Europe officials are the subject of agricultural information service (Li Bai. et al., 2006), in addition to the official, agriculture information service industry association (including organization, agricultural chamber) and futures market and insurance institutions to provide information service also occupied very big one part, play an important role in the agricultural risk prevention. In addition, South Korea established level from agricultural service system, the collection scientific research, promotion and training trinity, unified in agricultural service system, process is simplified and concentrated, promote the new leadership of rural sports.

The common features are formed when all the agriculture information service system are constructed, namely government organizations from macroscopically management and coordination in the executive departments, and clear responsibilities of collaboration; Second, the information service, information service, diversification of diversification, such as France; Third, pay attention to strengthen service environment from scientific research, education to ensure service system.

\subsection{China's Status}

Compared with the developed countries, the Chinese rural information service system construction starts relatively late, construction of agricultural information system has 
made significant achievements. Since 1995, China agriculture proposed involving agricultural informatization construction "JinNong project", based on Countries with large agricultural products market, emphasis, main agricultural education scientific research units and the agricultural professional societies, associations, agricultural and rural informatization are accelerated and promoted, agriculture comprehensive management and service information system" is established. The agricultural basic database, the national agricultural monitoring, forecast and warning, the macroeconomic regulation and control and decision-making service application system, agricultural production situation and crop production forecast system for agricultural development are established and perfection, and play an important role in recent 5 years. At present, the provincial department of agriculture, $97 \%$ of the prefecture (city) and $80 \%$ of the county agriculture department has information management and service, 64 percent of the information service, the township set up more than 20 million people in the development of rural feedback team, preliminary build from central to local agricultural information system.

Information technology development and application achieve positive progress. the information application system of the administrative examination and approval and the government office network office automation, scheduling NongQing scheduling, satellite communication, remote sensing, agriculture and animal epidemic information use the information technology are developed by the agriculture department. Department of agriculture, according to the management and service requirement, information system is developed which is related soil testing formula, pest control, basic farmland management. It effectively promotes the agricultural department of e-government, for accelerating the development of modern agriculture, the narrowing of "digital divide" plays a positive role in promoting (Ministry of Agriculture PRC., 2008).

At present, information service work of agriculture, countryside and Peasant is developing, it covers market monitoring warning system of the main agricultural products, and provides strong basis for the leadership, macro decision ; Information release which provides timely information industry of agricultural economy for farmers by the ministry of economic information standard calendar; It plays more and more major role in the promoting agricultural, the rural economy development, and the construction of new countryside by coordinating the agriculture information service work. There are 4 million the industrialization of agriculture leading enterprise, 17 million rural cooperative intermediary organizations, 61 million administrative villages, 95 million agricultural production and operation, and 240 million rural agent in our country, they can accept the department of agriculture information service by information networks and other forms.

\section{The Current Problems}

Agricultural informatization construction of our country is still in the initial, but compared service ability of the information service system with government, enterprises and the demand of agriculture information service, compared modern agriculture and the construction of socialist new countryside with the overall requirements of information work, compared with the developed countries in market economy, there is still a relatively large gap. Current outstanding problems mainly include: 
1) The agricultural informatization regulations system is not perfect, the agriculture information standardization is lag;

2) Weak infrastructure and farmers in developing the information service of the "last mile" problems have not been solved;

3) Information collection and collection channels are not standardization, information resource is shortage, information content of practicality is weak, quality need to be promoted, and information resource integration is difficult;

4) The share degree of Existing hardware resources and information resources is low, and does not form the effective mechanism of sharing;

5) The function of agricultural information, for example Radio, television, newspapers, telecommunications, media communication, has not been fully developed and integration, support ability of information platform technology is not adequately;

6) Peasants culture quality is low, awareness of information is weak, and information ability is not strong;

7) The percentage of The agricultural population of Internet users is low, agricultural sites are less, practical contents are also less, unwrought depth, using low degree, application service ability is bad;

8) The construction of agricultural team is lag, the demand of work can not satisfy by the personnel quantity, and service ability;

9) The degree of marketing is not high, the agricultural product market of electronic business affairs still not completely, commodities and services network level is low;

10) Agricultural information service system is not perfect, the agricultural informatization development level of regional of the middle, east and west is serious imbalance, and differences of regional development are very serious.

In view of the above problems, regional agricultural comprehensive information public service platform model and application research is put forward in this paper, and the agriculture information service of the "last mile" problem of agricultural information platform, and integration of information resources sharing, and agricultural informatization service standard lag issues are solved, it is an important realistic significance for perfecting the agriculture information service system.

\section{Development of Dynamic Analysis}

The tendency of our agricultural, rural informatization construction is following:

1) The government's leading tendency. Public information service is provided as the important functions of the government, the government must attach great importance to, overall planning, and investment, speed up the construction on which the government must play a leading role

2) The complicated trend of demand. Different departments, various industries, of all kinds' enterprise, cooperative organizations and farmers have different subjects such information needs. On the demand of information quality, effective customized information becomes main stream. On the demand of information on the subject, the strong demand of farmers, various enterprises and intermediary organizations are also increasingly urgent needs. 
3) The trend of the diverse channels. In the information services, multi-channel, more comprehensive application, modes means are emerge. "SanDian unity" information service in the background is the one of the effective way.

4) The trend of work. Agricultural information system construction includes agricultural production, processing, distribution and scientific education, promoting technology, consumption and other aspects, enrich the connotation of work, the extension of agricultural industries, and combining the closer, interweave propulsion trend.

5) The development trend of socialization. In recent years, the development of government leading practice showed that, the social forces in agricultural information system construction is the inevitable choice.

6) Precision trend of Production. Precision agriculture based on the global positioning system (GPS) and geographic information system (GIS), information collection and management system of farmland, intelligent decision support system of agricultural machinery system and system integration technology, becomes the core of agricultural informatization development.

\section{The Research of Agricultural Information Construction Framework}

\subsection{The Nature of Agricultural Information Construction Framework}

Agricultural information construction framework is a whole of many elements, which integrates information collection, possessing, communication, application and so on; the purpose is to provide technology and organization of agricultural informatization and security. Its main function is to collect information on the rural economy, processing, storage and transmission by feedback. Firstly, the governments and the relevant departments for the agricultural development plan and guide to provide the scientific basis as farmers, merchants and agricultural market. Secondly, it provides timely and accurate information service for farmers, merchants and agricultural market, accelerates the process of marketing of rural economy. Rural information service system provides information environment of the order transparent, information network of perfect accessibility and information service of high efficient, it is significant and profound influence on rural economic development.

\subsection{The Mode of Agricultural Information Construction Framework}

Notice of The national agricultural and rural informatization construction framework (2007-2015) by the issuance of agriculture of March 2008(Ministry of Agriculture PRC., 2008),pointed out: basic framework of our agricultural and rural informatization construction consists mainly in information infrastructure, information resources, talents, service and application system, and the development of the system, operation mechanism, whose rural economic, political, cultural and social fields, etc. study and formulate relevant software and hardware technology standards, data acquisition and processing standards, information, formulate standards, pay attention on information acquisition, storage, processing, processing standards and norms, accelerate information services, agricultural information classification and coding standard can be formulated quickly. 
Now, there is not standard of agricultural information construction framework in China, through the research and analysis standard of e-government standard (rules) and the ministry of agricultural and rural informatization construction, the general framework of agricultural information service system frame model is put forward, as shown in Fig1.

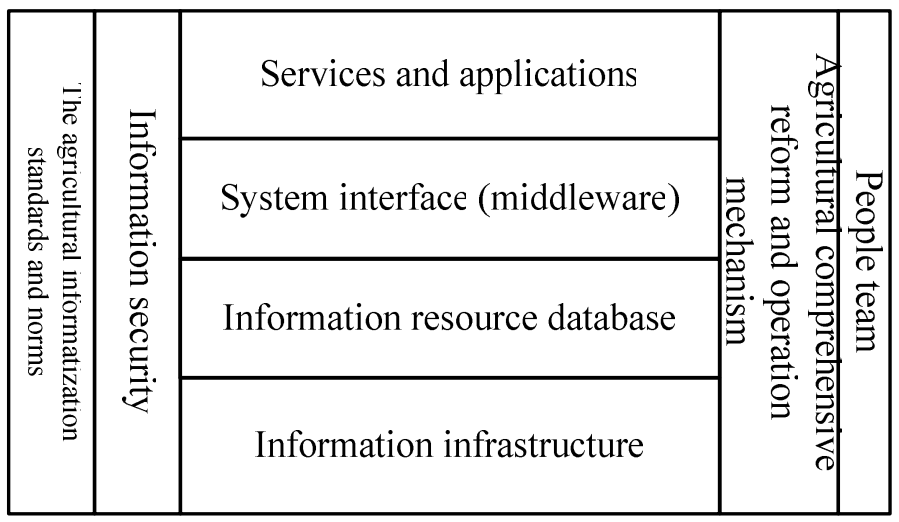

Fig. 1. The mode of agricultural information construction framework

Agricultural informatization basic framework consists mainly in rural economic, political, cultural and social fields of information infrastructure, information resource database, system interface, service and application system, talent team, agricultural comprehensive reform and the operation mechanism of agricultural informatization, information security and standard and standard etc.

1) The information infrastructure

It mainly includes network infrastructure, information technology equipment. Network infrastructure mainly has the computer network, the communication network and broadcast television, newspapers, magazines and billboards. Information technology basic equipment mainly refers to the development of information technology and popularization and application of the necessary facilities.

2) System interface layer

System interface layer is a system which the agricultural informatization construction to meet different levels of real-time information collection, transmission and exchange and sharing, service.

3) Information resource database

It is mainly includes science, technology, markets, policies, regulations, culture, education, health, and other information resources database. It serves the participants of production and living, and other social activities in the agriculture and rural.

4) People team

A practical and efficient service team is built, the information service mode innovation is strengthened, the applicability and effectiveness and scientific of the rural information service is improved. 
5) Services and applications system

It mainly includes service and information technology application. Information service combines with rural economy, social development of the actual, the development of modern agriculture, basic conditions of the existing information, the industrialization of agriculture and rural economic, the need of cooperation organization.

6) Information security

It mainly includes information security facilities, technical solutions, systems and equipment in order to ensure safe operation.

7) The standards and norms of agricultural informatization

It consists of the general standard, application standards, safety standards and infrastructure construction, management and service integration of standard; including agriculture information resources development and sharing, network (station) construction management, information service, information technology development and application, safety and security, etc.

8) Agricultural comprehensive reform and operation mechanism

It mainly includes the mechanism which is the agricultural informatization development, deepening reform of administrative system and promoting each other and common development; and forms the government-leading, market and other social forces joint participation of multiple input mechanism, and forms sustainable development mechanism of agricultural and rural informatization.

\section{Conclusion}

Information infrastructure is the basic conditions of agricultural informatization construction. System interface layer is the data exchanging platform of agricultural informatizition. It implements the data exchange function between the different applications. Information resource databases are the important content of agricultural informatization construction. Service and application system is the starting point and the foothold of agricultural informatization construction. Information security is the running guarantee for agricultural informatization construction. Agricultural informatization standardization is the key link of agricultural informatization construction and development. Agricultural comprehensive reform and the operation mechanism of agricultural informatization is the fundamental guarantee.

Agricultural information service system is the basic work of agricultural informatization construction, from the theory and application situation of agricultural informatization, compares and analyses the typical agricultural information system, the agricultural informatization service system structure is put forward, relevant laws and regulations of agricultural informationization construction is accelerate formulate, the perfect work system is established, agricultural and rural informatization construction standardization and institutionalized are promoted, it is an important meaning to construct the agricultural informatization engineering standards and norms.

\section{References}

Li, Y.: Study of agricultural information service system, China Agricultural University, PhD thesis, pp. 34-35 (2005) (in Chinese)

Xue, L., Fang, Y.: Agricultural Informatization, vol. 2, pp. 218-230. Jinghua Press, Beijing (1998) (in Chinese) 
Zhao, J., Wang, Y.: Summary Research on Agricultural Informatization in and Abroad. Document, Information \& Knowledge 6, 80-85 (2007) (in Chinese)

Zhang, X.-y.: Study on strengthening the construction of agricultural information system. Agricultural economic problems 1, 22-24 (2003) (in Chinese)

Yang, Y.: Concerning the development and enlightenment of Japanese agricultural informatization. Modern Japan's economy 6, 62-64 (2005) (in Chinese)

Guo, Z.: See the agriculture information service in the agriculture information service network construction from France-training report of the agriculture information service network in France. Feed wide-angle 4, 28-29 (2000) (in Chinese)

Bai, L., et al.: Mode and enlightenment of Euro agriculture information service. World Agriculture 1, 33-35 (2006) (in Chinese)

Ministry of Agriculture PRC. Construction Planning of The 11th five-year plan period of National Agricultural Information System by the ministry of agriculture (2008) (in Chinese), http: / /www.agri.gov.cn/jhgb/t20080321_1029961.htm

Ministry of Agriculture PRC. The notices about National Agriculture and Rural Informatization Construction Framework (2007-2015) by the ministry of agriculture (2008) (in Chinese), http://www.agri.gov.cn/jhgb/t20080321_1029943.htm 